\title{
Soybean Improvement: Achievements and Challenges
}

\author{
Joseph W. Burton • Lilian Miranda
}

received: 8 July 2013 , accepted: 10 July 2013
published online: 28 October 2013
(C) 2013 IFVC
doi: $10.5937 /$ ratpov50-4158

Summary: Soybean is a major source of vegetable protein and oil in the world. Worldwide demand continues to be high and production has more than doubled in the past 20 years to a total of 264.2 million metric tons in 2011 (National Agricultural Statistics Service 2012). Much of this increase has been due to increased planting in Argentina and Brazil. But, there have been genetic gains as well. We now have powerful genetic tools and these will be useful in gene discovery and in developing selectable markers for those genes. But for traits that are quantitative and multigenic, marker assisted selection may not be practical. We are facing unprecedented changes in our climate which will require resourceful use of the new genetic tools along with standard plant breeding methodology to maintain soybean productivity and quality.

Key words: abiotic stress, demand, disease resistance, genetic yield potential, genome, herbicide tolerance, pest resistance, plant breeding, seed composition, soybeans

\section{Introduction}

Soybean is a major source of vegetable protein and oil in the world. Worldwide demand continues to be high and production has more than doubled in the past 20 years to a total of 264.2 million metric tons in 2011 (National Agricultural Statistics Service 2012). Much of this increase has been due to increased planting in Argentina and Brazil. But, there have been genetic gains as well.

\section{Achievement 1: Increased genetic yield potential}

In the United States, average yield increase per hectare from 1972 to 1998 was $31.2 \mathrm{~kg} \mathrm{ha}^{-1}$ each year (Specht et al. 1999). Beginning in the early 1990s, many of the smaller soybean breeding seed companies were purchased by what has now become the big three - Monsanto, DuPont Pioneer, and Syngenta. Recently Bayer Crop Science has joined this group and has begun soybean breeding research. Since then, the average gains have been slightly lower at $29.9 \mathrm{~kg} \mathrm{ha}^{-1}$. Based on public

J.W. Burton*

Department of Crop Sciences, North Carolina State University, Box 7620 Raleigh, NC 27695, USA

e-mail: ltta@ncsu.edu

L. Miranda

USDA-ARS, Box 7631, North Carolina State University, Raleigh, NC 27607, USA and proprietary plant breeding data, Specht et al. (1999) estimated that about $80 \%$ of that yield increase has been due to genetic improvement.

These achievements in soybean production are impressive, but there are challenges ahead which may slow the rate of improvement. Possibly the greatest challenge to increased productivity is global warming and climate change. In 2012, a severe drought in the United States corn-belt caused an $8.6 \%$ decrease in soybean yields from the previous two years. In addition some water resources are being depleted. For example, the Ogallala aquifer which isused to irrigatecrops in the western states, is being used up (Brikowski 2008). Now a large number of wells into this aquifer no longer provide water. While increases in $\mathrm{CO}_{2}$ might be expected to increase productivity, effects of climate change may counteract those increases. The severe drought in the U.S. corn-belt in 2012, is an example of what the future may hold. In the U.S., it is doubtful that significantly more land will be used for soybean production. At least in the foreseeable future, it is unlikely that land used for maize production will be converted to soybean production, and other land resources suitable for soybean production are not available. It may be possible to bring more hectares into soybean production in South America, but that use must be weighed against the need to preserve natural vegetation and water resources, as well as a need to produce other food crops. 
Another challenge to increased productivity is a lack of genetic diversity. In North America, Gizliceet al. (1994), using pedigree relationships, showed that 35 ancestors contributed to $95 \%$ of genes in the cultivars released between 1947 and 1988. Furthermore, 16 of those 35 contributed $85 \%$ of the genes. More recently, a study by Hyten et al. (2006) compared sequence diversity within and between four populations representing elite North American soybean cultivars, Asian landrace founders of those elite cultivars, Asian landraces with no known relationship to the founding stock and wild soybean (G. soja) accessions. This research showed that $79 \%$ of rare alleles found in Asian landraces had been lost in modern cultivars. This narrow genetic base would be duplicated in South American soybean production to the extent that South American cultivars derive from North American germplasm. Plant introductions from the U.S.D.A. germplasm collection have been used in breeding programs. But, they have been used primarily as a source of genes for disease and pest resistance in backcrossing programs, and therefore, have contributed little to overall diversity. Another factor which may result in less genetic diversity is the consolidation of smaller seed companies into the three large corporations previously mentioned and the use of utility patents to protect released cultivars (Mikel et al. 2010). This has resulted in reduced germplasm exchange. Over time, the germplasm pool within each corporation may become narrower. In addition, emphasis in private breeding companies is on adding traits such as disease resistance and herbicide tolerance to already successful cultivars (C. Tinius, personal communication). This will also contribute to a narrower gene pool as it reduces genetic recombination and research on genetic diversity.

Some public breeding programs have placed an emphasis on increasing the genetic diversity by developing germplasm with increased productivity that is at least partially derived from exotic sources. Carter et al. (2004) has identified Chinese cultivars which yield 80 to $88 \%$ as much as elite U.S. cultivars. High yielding cultivars and germplasm have been developed using these and other introductions from the U.S.D.A. germplasm collection (Carter et al. 2010, Nelson \& Johnson 2011, Chen et al. 2011, Nelson \& Johnson 2012). Standard plant breeding practices have been used for this, e.g. hybridization between adapted high yielding cultivars, followed by inbreeding and selection, sometimes with backcrossing.

\section{Achievement II: Sequencing and mapping the soybean genome}

A major achievement for soybean improvement is the development of consensus maps for the 20 linkage groups of the soybean genome and DNA sequencing of the genome. Four consensus maps have been published beginning with the first in 1995 (Shoemaker \& Specht 1995, Song et al. 2004, Choi et al. 2007, Hyten et al. 2010). The most recent map published by Hyten et al. (2010) has between 175 and 418 markers on each linkage group. There are 3792 SNP markers, 1006 SSR markers, 664 RFLP markers, and 38 other markers for a total of 5500 markers. In addition, they developed a subset of 1536 biallelic SNP markers called the Universal Soy Linkage panel (USLP). These were chosen by a set of criteria which insured a good distribution along each chromosome. They noted that there were 16 gaps greater than $10 \mathrm{cM}$. But, there were SSR markers in most of those gaps. They did a pairwise comparison of the 96 landrace genotypes and 96 elite cultivars to determine how many could be expected to be polymorphic in biparental crosses. Based on this comparison, an average 458 SNPs could be expected to be polymorphic in elite $\mathrm{x}$ elite crosses. That increased to 590 polymorphic SNPs in elite $\mathrm{x}$ landrace crosses.

This USLP is being used to genotype the entire USDA soybean germplasm collection. Because this resource was developed with public funds (ARS and United Soybean Board), it will be published and be available to the public as information about a particular germplasm, along with other information about that accession in the collection. This will be very useful for plant breeders who use the germplasm for association mapping studies, parental selection, genome wide selection, and as a source for needed genetics.

The soybean genome of the cultivar 'Williams 82 ' has been sequenced using a whole-genome shotgun approach integrated with consensus maps previously discussed (Schmutz et al. 2010). Soybean is a diploidized ancient polyploidy with two genome duplications approximately, 59 and 13 million years ago; Schmutz et al. (2010) reported that nearly $75 \%$ of the genes have multiple copies. This has important ramifications for plant breeding and is probably an important basis for quantitative variation.

Quantitative trait loci have been identified for many traits, but most have never been used for marker assisted selection. In most cases, actual genes affecting the quantitative trait have not been identified and linkage of the QTL to the causative gene may not be close enough for effective selection. However, information on QTL positions combined 
with the now available genome sequence can be used to determine the genetic basis of oligogenic traits. For example, Maroof et al. (2009) was able to determine the gene responsible for a low phytate mutant comparing the Williams82 DNA sequences of candidate genes in regions of linkage groups known to have low phytate QTL with DNA sequences of the same segments in the low phytate mutant line CX-1834-9 (Wilcox et al. 2000).

The challenge going forward will be to use these resources for breeding in an effective and cost efficient way. From a plant breeding point of view, the genetic information is useful for marker assisted selection when one or two genes can be identified that provide the desired phenotype, as in the low phytate example. But truly quantitative traits, where multiple genes are involved on several linkage groups, provide a much more difficult selection problem - even if the genes are known with selectable markers associated with each one. For multigenic traits, such as yield, QTL are usually population specific and population sizes required to capture all favorable alleles become quite large. Wang et al. (2007) suggested using $F_{2}$ enrichment (selection of $\mathrm{F}_{2}$ plants that are homozygous or heterozygous for favorable alleles), prior to inbreeding as a way to reduce population size.

A possible method for genome wide selection has been proposed by Sebastian et al. (2010) which they called context-specific marker-assisted selection. It has been adopted by DuPont Pioneer in what they call Accelerated Yield Technology. They have identified genomic yield QTL "hotspots" based on frequency shifts that have occurred in their soybean germplasm over $50+$ years of selection for yield and have 600 genomic markers associated with these regions. So for any given biparental $\mathrm{F}_{2}$ population, they will have a set of QTL that are segregating. In an initial single replicate field experiment, conducted at 3 or more target environments (i.e. context environments), they can determine which of the yield QTL alleles are favorable and then select on those going forward in their inbreeding and cultivar development program.

Another genome wide selection program for selfpollinated species has been suggested by Bernardo (2010). He provides a simulation example for barley that might be difficult to apply in soybean. But his methodology would be useful for devising genome wide selection methods that could work for soybean.

\section{Achievement III: Herbicide Tolerance}

Herbicide tolerance has been a mixed blessing for soybean improvement. But it has had a major impact on soybean production. The first herbicide tolerant soybeans were resistant to ALS (acetolactate synthase) inhibiting herbicides, e.g. sulfanyl-urea. This was a naturally occurring mutant discovered by Dupont. STS (sulfanyl-urea tolerant soybeans) cultivars were introduced in 1994. RoundUp Ready (glyphosate resistant) cultivars were released in 1996 by Monsanto. Glyphosate resistance is provided by a transgene of microbial origin, which inhibits a phosphate synthase enzyme (EPSPS) (Castle et al.2004). It was rapidly adopted by farmers throughout soybean producing regions in the U.S. and Argentina, and some years later, in Brazil. It provided some production advantages:

1. Glyphosate is a low cost herbicide with low environmental impact

2. It enables use of minimum tillage. Soybeans can be drilled and glyphosate applied over the plant canopy, eliminating cultivation with lower fuel costs.

But there are disadvantages:

1. Seed costs are high. Technology is proprietary and farmers are unable to save seeds for replanting.

2. Yields, at least initially, were lower, because the transgene was backcrossed into existing cultivars.

3. Continual use has selected glyphosate resistant weeds in some fields - particularly Amaranthus species - making the herbicide essentially useless in some regions.

4. RoundUp resistant volunteer plants from a previous crop have to be dealt with.

Because glyphosate herbicides were so popular, research on other herbicides was discontinued. Now older herbicides are being used, in addition to glyphosate with some concern that weeds will develop which are resistant to those herbicides.

Other types of herbicide resistant soybeans are being developed. Currently there are two other herbicide resistant soybeans being used, GAT soybeans - that detoxify glyphosate, and glyphosinate resistant (Liberty Link) soybeans. Varieties with resistance to two different herbicides have been developed. There are other herbicide transgenes which might be used in the future, including resistance to 2-4-D and Dicamba (Behrens et al. 2007). These could probably be deployed in soybean fields if the need arises, but research and the approval process would be costly.

\section{Achievement IV: Improved Seed Composition}

Grain type soybeans are processed into two commodities, oil and protein meal. Both are economically important. In the U.S. there has 
been a continual increase in the use of both. There has been breeding efforts to increase the concentrations of both oil and protein in seeds. There is considerable genetic variation in both traits. In the USDA germplasm collection protein varies from $35.1 \%$ to $56.8 \%$ on a dry weight basis, and the oil concentration range is $8.3 \%$ to $27.9 \%$. The two tend to be negatively correlated. In recent research with two populations that were randomly intermated for 26 generations, thereby dissipating most of the linkage disequilibrium, that negative correlation between the two traits was maintained at about $\mathrm{r}=-0.6$. Nevertheless, some progress has been made in changing the two traits separately. A major protein QTL, found in Glycine soja, has been mapped to linkage group I and increases protein by 2 percentage points (Nichols et al. 2006). A high oil germplasm was developed by recurrent selection, N98-480, and was used as a parent or the high oil cultivar, NC-Raleigh. QTL for both protein and oil content have been published and a compilation of references have been made by Wang and Grant (2010). Although efforts to improve the two traits simultaneously have been challenging, a recent study by Eskandari et al. (2013) provides some insights on how to address this issue. They identified a QTL that has a positive effect on both oil and protein concentration and also several QTL that increase oil but do not decrease protein or yield.

Much research on seed composition has been focused on quality traits. For protein meal, major objectives include improving the nutritional quality by increasing sulfur amino acids, cysteine and methionine; reducing poorly digestible components, phytic acid and the oligosaccharides, raffinose and stachyose. For oil, much emphasis has been placed on improving oxidative stability by decreasing the linolenic fatty acid from $9 \%$ to $3 \%$ or less, and increasing the oleic fatty acid from $22 \%$ to more than $75 \%$. Additional objectives include decreasing the saturated palmitic acid, which increases levels of cholesterol in blood and is presumably bad for heart health; and increasing the saturated stearic acid which does not affect cholesterol. Increasing saturates would provide an oil that can be used for shortening.

Progress in breeding for altered amino acid content has been impeded by difficulties in accurately measuring their content in seed protein. Measurement methods have been slow and costly. It is possible to measure amino acid content by infrared reflectance. If that provides acceptable results, breeding for altered amino acid will become cost effective and research in this area should increase. Another challenge, however, is genetic diversity. Germplasm resources that have been studied seem to indicate fairly low levels of genetic variation for these two amino acids. Thus, a good screen of the germplasm collection is needed.

Another strategy for altering amino acid content is to change the relative concentration of the two main storage proteins, glycinin (11S) and $\beta$-conglycinin (7S). Increasing l1S which has higher levels of sulfur amino acids at the expense of $7 \mathrm{~S}$ should result in higher concentrations of methionine and cysteine. These components may also be measured by infrared reflectance (Delwiche et al. 2007). QTL for these have been identified.

Phytic acid is a storage form of Phosphorous (P) in soybean seeds that is not bioavailable to animals. As such, it is in excreta and is a major source of water pollution, where there are swine and poultry feeding facilities. Low phytate soybeans have been developed and mutant genes responsible for the phenotype have been discovered and mapped (Walker et al. 2006). The mutants do not decrease $\mathrm{P}$ in the seeds. Rather the P levels remain as digestible phosphate (Israel et al. 2007). These mutants can cause reductions in germination. But, there is evidence that this can be overcome with breeding (Maupin \& Rainey 2011).

It is possible to genetically alter stachyose and raffinose content in seeds. This has the pleiotropic effect of increasing sucrose (Skoneczka et al. 2009). Higher sucrose content increases the energy that can be metabolized from protein meal. Both reducing phytic acid and increasing sucrose seem to have a neutral effect on seed yield. So it should be possible to produce high yielding varieties with both traits that could be processed to a higher quality meal.

The biosynthetic pathway of seed fatty acids is well understood and mutants at various stages in that pathway are available. Some of the mutants were developed by mutagenesis, while others were naturally occurring and were discovered in the USDA germplasm collection. Mutations in the GmFAD2-1A and GmFAD2-1B genes encoding $\omega-6$ desaturases that catalyzes the conversion of oleic acid to linoleic acid, produces a high $(\geq 75 \%)$ oleic phenotype (Pham et al. 2010). Mutations in the GmFAD 3 genes that encode the $\omega-3$ desaturases that catalyzes conversion of linoleic tolinolenic acid, produce a low $(\leq 3 \%)$ linolenic phenotype (Pham et al. 2012). Oil from these soybeans is very stable in frying applications. The GmFAD2 genes can also be down regulated transgenically to produce a high oleic phenotype. Currently Monsanto and DuPont Pioneer have soybean cultivars in production with an oil profile of $77 \%$ oleic acid and 3\% linolenic acid. From these varieties, high 
oleic soybean oil is being processed and marketed. There is high demand by the vegetable oil industry for this type of soybean. But the challenge is to get yield levels equivalent to standard soybean cultivars so that enough of these varieties will be produced to provide the oil needed.

The use of partial hydrogenation to produce solid fats for margarine and shortening produces trans fatty acids. Labeling laws require that levels of trans fats in food products be included on the food product labels. This has greatly curtailed the use of soybean oil for those products. It has been replaced by cotton seed, palm and palm kernel oils. Now mutants in genes that encode $\Delta 9$-stearoylacyl carrier protein-desaturases (SACPD-B and SACPD-C) (Hammond \& Fehr 1983, Zhang et al. 2008, Boersma et al. 2012, Ruddle et al. 2013) provide a $14 \%$ stearic acid phenotype. If stearic acid can be increased to $20 \%$, these materials will have total saturates (palmitic + stearic fatty acids) that would be suitable for margarine and shortening. Here again the challenge will be to produce high yielding varieties and then getting enough production with identity preservation to serve the needs of the oil industry.

\section{Achievement V: Pest and disease resistance/ tolerance}

There have been achievements in development of genetic resistance or tolerance to diseases and pests. In the United States, commercial cultivars are marketed as being resistant or tolerant to one or more of the following:

$\begin{array}{ll}\text { White mold } & \begin{array}{l}\text { Sclerotinium rolfsii } \\ \text { Fusarium solani f. sp. } \\ \text { Slycines }\end{array} \\ \text { Brown stem rot } & \begin{array}{l}\text { Phialophora gregata } \\ \text { f. sp. sojae }\end{array} \\ \text { Phytophthora root and stem rot } & \begin{array}{l}\text { Phytophthora sojae } \\ \text { Cercospora sojina }\end{array} \\ \text { Froyeye leaf spot } & \begin{array}{l}\text { Diaporthephaseolorum } \\ \text { var.carlivora }\end{array} \\ \text { Stem canker } & \text { Macrophomina phaseolina } \\ \text { Charcoal rot } & \text { Phakopsora pachyrhizi, } \\ \text { Soybean rust } & \text { a Potyvirus } \\ \text { Soybean mosaic virus } & \text { A Comovirus } \\ \text { Bean pod mottle virus } & \text { Heterodera glycines } \\ \text { Soybean cyst nematode } & \text { Meloidogine arenaria or } \\ \text { Root know nematode } & \text { incognita }\end{array}$

Putative QTL have been published for most of the preceding (Wang \& Grant 2010).

Pathogens and pests change in response to their environment and their host plant. For example, using cultivars which were resistant to a particular race of soybean cyst nematode can result in nematode population shift, so that particular genetic resistance is no longer effective. Race shifts in other pathogens are well known with similar effect. Thus the challenge for soybean improvement is to maintain productivity as current diseases and pests change and as new ones arrive. Strategies vary depending on the pathogen or pest. These include the following:

1. Traditional breeding for resistance and searching for new resistant germplasm resources, including QTL discovery.

2. Improving identification of pathogenic organisms to determine those which are most virulent.

3. Fine mapping QTL to permit MAS (Hyten et al. 2007, Kim et al. 2010).

4. Find the resistance gene using gene silencing techniques and/or QTL comparison of resistant susceptible isolines.

5. Examine the interaction between host and pathogen genotypes.

6. Select improved plant defense genes - innate plant resistance.

7. Using endotoxin and proteinase inhibitor transgenes to provide insect resistance (Babu et al. 2003).

In the past decade a new disease, soybean rust, and two new pests, soybean aphid and Kudzu bug have emerged in the U.S. Soybean aphid has been a problem in northern production regions, but is moving southward. Kudzu bug (Megacopta cribraria), the newest insect pest, emerged in the southeastern U.S. and is moving northward. The search for resistance is only beginning. The rapid response of selection to the previous new arrival, the soybean aphid (Kim et al. 2008), provides a model and hope that resistance to this insect can also be identified. In China, research on two other insects, the bean pyralid and pod borer, may provide information and germplasm that can be helpful in finding resistance to the Kudzu bug.

Soybean rust (Phakopsora pachyrbizi) arrived in the U.S.A. in 2004 and caused much concern and generated much research. The immediate response among plant pathologists was to develop a regional system of test plots to monitor and predict pathogen spread. This was used to make fungicide application recommendations to farmers in regions where the disease was found. Germplasm screening began immediately and dominant genes which provide resistance have since been discovered (Chakraborty et al. 2009). 


\section{Achievement VI: Improved resistance to abiotic stress}

Abiotic stresses that have received the most attention in the U.S. are drought, iron deficiency, aluminum toxicity, soil salinization, and water logging. Drought has been identified as the most limiting to productivity (Purcell \& Specht 2004) and probably the most difficult to address in plant breeding. It is a physiologically complex trait, and it is difficult to provide a breeding population with a consistent drought environment that is useful for selection and at the same time typical of standard farm production practices. When irrigation capability is present, plant breeding research for drought tolerance has been conducted on deep sands because they dry out rapidly, even after a heavy rainfall (T.E. Carter, Jr., personal communication). Germplasm has been screened on deep sands, and selected based on ability to wilt slowly under dry conditions. Greenhouse environments have also been used (Hufstetler et al. 2007). Traits that have been studied include increased water use efficiency, decline in whole plant water use during a soil water deficit, low leaf epidermal conductance, and quantity of dry matter accumulated per unit of soil water transpired. The ability of plants to continue to fix $\mathrm{N}$ in dry conditions is another trait that seems to be important (Sinclair et al. 2007). Recently there is evidence that canopy temperature may be important (T.R. Sinclair, personal communication).

Iron deficiency chlorosis (IDC) is a problem on calcareous soil in the Midwestern USA and in South America. Selection for resistance to IDC has been successful and resistant cultivars are available. QTL mapping studies have been conducted (Lin et al. 1997, Charlson et al. 2005), but to my knowledge there is no MAS being used at this time.

Root pruning due to aluminum toxicity makes plant response to aluminum appear as drought symptoms. Thus, germplasm tolerant to drought are sometimes tolerant to aluminum (Goldman et al. 1989).

Germplasm has been screened for tolerance to water logging and salinization. Germplasm has been identified with some tolerance to flooding, and QTL mapping has been done (Nguyen et al. 2012, VanToai et al. 2010). Salt tolerant germplasm has been identified and methods for screening have been published (Lee et al. 2008).

\section{Conclusion}

We now have powerful genetic tools and these will be useful in gene discovery and in developing selectable markers for those genes. But for traits that are quantitative and multigenic, marker assisted selection may not be practical. We are facing unprecedented changes in our climate which will require resourceful use of the new genetic tools along with standard plant breeding methodology to maintain soybean productivity and quality.

\section{References}

Babu, R.M., Sajeena, A., Seetharaman, K., \& Reddy, M.S. (2003). Advances in genetically engineered (transgenic) plants in pest management - an overview. Crop Protection, 22, 1071-1086.

Behrens, M.R., Mutlu, N., Chakraborty, S., Dumitru, R., Jiang, W.Z., Lavallee, B.J., . . Weeks, D.P. (2007). Dicamba resistance: enlarging and preserving biotechnology-based weed management strategies. Science (Wash), 316, 1185-1188.

Bernardo, R. (2010). Genomewide Selection with Minimal Crossing in Self-Pollinated Crops. Crop Sci., 50, 624-627. [electronic resource].

Boersma, J.G., Gillman, J.D., Bilyeu, K.D., Ablett, G.R., Grainger, C., \& Rajcan, I. (2012). New mutations in a delta-9stearoyl-acyl carrier protein desaturase gene associated with enhanced stearic acid levels in soybean seed.Crop Sci., 52, 1736-1742.

Brikowski, T.H. (2008). Doomed reservoirs in Kansas, USA?, Climate change and groundwater mining on the Great Plains lead to unsustainable surface water storage. Journal of bydrolo$g y, 354,90-101$. [electronic resource].

Carter, T.E., Nelson, R.L., Sneller, C., \& Cui, Z. (2004). Genetic Diversity in Soybean. In H.R. Boerma \& J.E. Specht (Eds.), Soybeans: Improvement, Production, and Uses. (pp. 303416). Madison, Wisconsin: American Society of Agronomy, Inc.; Crop Science Society of America, Inc.; Soil Science Society of America, Inc..

Carter, T.E.J., Bowman, D.T., Taliercio, E., Kwanyuen, P., Rzewnicki, P.E., Burton, J.W., \& Villagarcia, M.R. (2010). Registration of N6202 Soybean Germplasm with High Protein, Favorable Yield Potential, Large Seed, and Diverse Pedigree. Journal of Plant Registrations, 4, 73-79. [electronic resource].

Castle, L.A., Siehl, D.L., Gorton, R., Patten, P.A., Chen, Y.H., Bertain, S., . . Lassner, M.W. (2004). Discovery and directed evolution of a glyphosate tolerance gene. Science, 304(5674), 1151-4. pmid:15155947

Chakraborty, N., Curley, J., Frederick, R.D., Hyten, D.L., Nelson, R.L., Hartman, G.L., \& Diers, B.W. (2009). Mapping and confirmation of a new allele at Rpp1 from soybean PI 594538A conferring RB lesion-type resistance to soybean rust. Crop Sci., 49, 783-790.

Charlson, D.V., Shoemaker, R.C., Cianzio, S.R., \& Bailey, T.B. (2005). Molecular marker Satt481 is associated with iron-deficiency chlorosis resistance in a soybean breeding population. Crop Sci., 45, 2394-2399. [electronic resource].

Chen, P., Ishibashi, T., Sneller, C., Rupe, J., Dombek, D., \& Robbins, R. (2011). Registration of R99-1613F, R01-2731F, and R01-3474F Soybean Germplasm Lines with Diverse Pedigrees. Journal of Plant Registrations, 5, 220-226. 
Choi, I., Hyten, D.L., Matukumalli, L.K., Song, Q., Chaky, J.M., Quigley, C.V., . . . Shoemaker, R.C. (2007). A soybean transcript map: gene distribution, haplotype and singlenucleotide polymorphism analysis. Genetics, 176(1), 685-96. pmid:17339218

Delwiche, S.R., Pantalone, V.R., Panthee, D.R., \& Pordesimo, L.O. (2007). Assessing Glycinin (11S) and Îø-Conglycinin (7S) Fractions of Soybean Storage Protein by Near-Infrared Spectroscopy. J Am Oil Chem Soc., 84, 1107-1115. [electronic resource].

Eskandari, M., Cober, E.R., \& Rajcan, I. (2013). Genetic control of soybean seed oil: I. QTL and genes associated with seed oil concentration in RIL populations derived from crossing moderately high-oil parents. Theoretical and Applied Geneti$c s, 126,483-495$.

Gizlice, Z., Carter, J., \& Burton, J. (1994). Genetic base for North American public soybean cultivars released between 1947 and 1988. Crop Sci, 34, 1143-1151.

Goldman, I.L., Patterson, R.P., \& Carter, T.E.J. (1989). A detrimental interaction of subsoil aluminum and drought stress on the leaf water status of soybean. Agron J., 81, 461-463.

Hammond, E.G., \& Fehr, W.R. (1983). Registration of A6 germplasm line of soybean (Reg. No. GP45). Crop Sci., 23, 192193.

Hufstetler, E.V., Earl, H.J., Carter, T.E.J., \& Boerma, H.R. (2007). Genotypic Variation for Three Physiological Traits Affecting Drought Tolerance in Soybean. Crop Sci., 47, 25-35. [electronic resource].

Hyten, D.L., Choi, I.Y., Song, Q.J., Specht, J.E., Carter, T.E.J., Shoemaker, R.C., ... Cregan, P.B. (2010). A high density integrated genetic linkage map of soybean and the development of a 1536 universal soy linkage panel for quantitative trait locus mapping. Crop Sci., 50, 960-968.

Hyten, D.L., Hartman, G.L., Nelson, R.L., Frederick, R.D., Concibido, V.C., Narvel, J.M., \& Cregan, P.B. (2007). Map location of the Rpp1 locus that confers resistance to soybean rust in soybean. Crop Sci., 47, 837-840.

Hyten, D.L., Song, Q., Zhu, Y., Choi, I., Nelson, R.L., Costa, J.M., . . Cregan, P.B. (2006). Impacts of genetic bottlenecks on soybean genome diversity. Proc. Natl. Acad. Sci. U.S.A., 103(45), 16666-71. pmid:17068128

Israel, D.W., Walker, D.R., Burton, J.W., \& Kwanyuen, P. (2007). Response of Low Seed Phytic Acid Soybeans to Increases in External Phosphorus Supply. Crop Sci., 47, 2036-2046. [electronic resource].

Kim, K.S., Bellendir, S., Hudson, K.A., Hill, C.B., Hartman, G.L., Hyten, D.L., ... Diers, B.W. (2010). Fine mapping the soybean aphid resistance gene Rag1 in soybean. Theoretical and Applied Genetics, 120, 1063-1071.

Kim, K.S., Hill, C.B., Hartman, G.L., Rouf, M.M.A., \& Diers, B.W. (2008). Discovery of Soybean Aphid Biotypes. Crop Science, 48(3), 923-928. [electronic resource]. doi:10.2135/ cropsci2007.08.0447

Lee, J., Shumway, C.R., Carter, T.E.J., Shannon, J.G., Smothers, S.L., Dunn, D., \& Villagarcia, M. (2008). Evaluation of a Simple Method to Screen Soybean Genotypes for Salt Tolerance. Crop Sci., 48, 2194-2200. [electronic resource].

Lin, S., Shoemaker, R., \& Cianzio, S. (1997). Mapping genetic loci for iron deficiency chlorosis in soybean. Molecular breeding: New strategies in plant improvement, 3, 219-229.

Maroof, M.A.S., Glover, N.M., Biyashev, R.M., Buss, G.R., \& Grabau, E.A. (2009). Genetic basis of the low-phytate trait in the soybean line CX1834. Crop Sci., 49, 69-76.

Maupin, L.M., \& Rainey, K.M. (2011). Improving emergence of modified phosphorus composition soybeans: genotypes, germplasm, environments, and selection. Crop Sci., 51, 19461955.

Mikel, M.A., Smith, H.H., Nelson, R.L., \& Diers, B.W. (2010). Genetic Diversity and Agronomic Improvement of North
American Soybean Germplasm. Crop Sci., 50, 1219-1229. [electronic resource].

National Agricultural Statistics Service. (2012). Agricultural Statistics 2012. United States: Agricultural Statistics, Department of Agriculture.

Nelson, R.L., \& Johnson, E.O.C. (2012). Registration of the high-yielding soybean germplasm line LG04-6000.Journal of Plant Registrations, 6, 212-215.

Nelson, R.L., \& Johnson, E.O.C. (2011). Registration of soybean germplasm line LG00-6313. Journal of Plant Registrations, 5, 406-409.

Nguyen, V.T., Vuong, T.D., Vantoai, T., Lee, J.D., Wu, X., Mian, M.A.R., . . Nguyen, H.T. (2012). Mapping of quantitative trait loci associated with resistance to Phytophthora sojae and flooding tolerance in soybean. Crop Sci., 52, 2481-2493.

Nichols, D.M., Glover, K.D., Carlson, S.R., Specht, J.E., \& Diers, B.W. (2006). Fine mapping of a seed protein QTL on soybean linkage group I and its correlated effects on agronomic traits. Crop Sci., 46, 834-839.

Pham, A.T., Lee, J.D., Shannon, J.G., \& Bilyeu, K.D. (2010). Mutant alleles of FAD2-1A and FAD2-1B combine to produce soybeans with the high oleic acid seed oil trait. BMC Plant Biology, 10, 195.

Pham, A.T., Shannon, J.G., \& Bilyeu, K.D. (2012). Combinations of mutant FAD2 and FAD3 genes to produce high oleic acid and low linolenic acid soybean oil. Theoretical and Applied Genetics, 125, 503-515.

Purcell, L.C., \& Specht, J.E. (2004). Physiological Traits for Ameliorating Drought Stress. In H.R. Boerma \& J.E. Specht (Eds.), Soybeans: Improvement, Production, and Uses, 3rd. (pp. 569-620). Wisconsin: Soil Science Society of America, Inc. Madison.

Raymer, P.L., \& Grey, T.L. (2003). Challenges in comparing transgenic and nontransgenic soybean cultivars. Crop Sci., 43, 1584-1589.

Ruddle, P.I.I., Whetten, R., Cardinal, A., Upchurch, R.G., \& Miranda, L. (2013). Effect of a novel mutation in a $\delta 9$-stearoylACP-desaturase on soybean seed oil composition. Theoretical and Applied Genetics, 126, 241-249.

Schmutz, J., Hyten, D.L., Song, Q.J., Thelen, J.J., Cheng, J.L., Xu, D., Hellsten, U., ... Goodstein, D. (2010). Genome sequence of the palaeopolyploid soybean. Nature (London), 463, 178183.

Sebastian, S.A., Streit, L.G., Stephens, P.A., Thompson, J.A., Hedges, B.R., Fabrizius, M.A., . . Hoeck, J.A. (2010). Context-specific marker-assisted selection for improved grain yield in elite soybean populations. Crop Sci., 50, 1196-1206.

Shoemaker, R.C., \& Specht, J.E. (1995). Integration of the soybean molecular and classical genetic linkage groups.Crop Sci., 35, 436-446.

Sinclair, T.R., Purcell, L.C., King, C.A., Sneller, C.H., Chen, P.Y., \& Vadez, V. (2007). Drought tolerance and yield increase of soybean resulting from improved symbiotic N2 fixation. Field Crops Res., 101, 68-71.

Skoneczka, J.A., Maroof, M.A.S., Shang, C., \& Buss, G.R. (2009). Identification of candidate gene mutation associated with low stachyose phenotype in soybean line PI200508. Crop Sci., 49, 247-255.

Song, Q.J., Marek, L.F., Shoemaker, R.C., Lark, K.G., Concibido, V.C., Delannay, X., ... Cregan, P.B. (2004). A new integrated genetic linkage map of the soybean. Theoretical and Applied Genetics, 109(1), 122-8. pmid:14991109

Specht, J.E., Hume, D.J., \& Kumundin, S.V. (1999). Soybean yield potential: A genetic and physiological perspective. Crop Sci, 39, 1560-1570.

van Toai, T.T., Thi, T.C.H., Thi, N.N.H., Nguyen, H.T., Shannon, J.G., \& Rahman, M.A. (2010). Flooding tolerance of soybe- 
an [Glycine $\max$ (L.) Merr.] germplasm from Southeast Asia under field and screen-house environments. Open Agriculture Journal, 4, 38-46.

Walker, D.R., Wilcox, J.R., Boerma, H.R., Scaboo, A.M., \& Pantalone, V.R. (2006). Genetic mapping of loci associated with seed phytic acid content in CX1834-1-2 soybean. Crop Sci., 46, 390-397. [electronic resource].

Wang, D., \& Grant, D. (2010). Molecular Mapping of Quantitative Trait Loci. In K. Bilyeu, M.B. Ratnaparkhe, \& C. Kole (Eds.), Genetics, Genomics and Breeding of Soybean. (pp. 91121). Enfield, New Hampshire: CRC Press.
Wang, J., Chapman, S.C., Bonnett, D.G., Rebetzke, G.J., \& Crouch, J. (2007). Application of population genetic theory and simulation models to efficiently pyramid multiple genes via marker-assisted selection. Crop Sci., 47, 582-590.

Wilcox, J.R., Premashandra, G.S., Young, K.A., \& Raboy, V. (2000). Isolation of high seed inorganic P, low-phytate soybean mutants. Crop Sci., 40, 1601-1605.

Zhang, P., Burton, J.W., Upchurch, R.G., Whittle, E., Shanklin, J., \& Dewey, R.E. (2008). Mutations in a $\Delta$ 9-stearoyl-ACPdesaturase gene are associated with enhanced stearic acid levels in soybean seeds. Crop Sci., 48, 2305-2313.

\title{
Poboljšanje soje: dostignuća i izazovi
}

\author{
Joseph W. Burton • Lilian Miranda
}

Sažetak: Soja je značajan izvor proteina i ulja na svetskom nivou. Svetska potražnja nastavlja da se održava na visokom nivou, a proizvodnja se udvostručila u poslednjih 20 godina, dostigavši iznos od 264,2 miliona metričkih tona u 2011. godini (National Agricultural Statistics Service 2012). Ovaj rast je posledica povećanog obima setve u Argentini i Brazilu, koja je takođe donela i genetsku korist. Danas imamo razvijene genetske alate od koristi pri otkrivanju gena i razvoju selektivnih markera za te gene. Sa druge strane, marker asistirana selekcija nije praktična za upotrebu pri analizi kvantitativnih i multigenskih osobina. Suočeni smo sa klimatskim promenama bez presedana koje uz standardnu metodologiju oplemenjivanja zahtevaju veštu upotrebu novih genetskih alata kako bi se zadržala produktivnost i kvalitet soje.

Ključne reči: abiotski stres, genetski potencijal za prinos, genom, oplemenjivanje biljaka, otpornost na bolesti, otpornost na štetočine, potražnja, sastav semena, soja, tolerantnost na herbicide 